\title{
The Role of Everolimus in the Treatment of Breast Cancer
}

\author{
José Pablo Leone ${ }^{1}$, Ricardo H. Álvarez ${ }^{2 *}$ \\ ${ }^{1}$ University of Pittsburgh Cancer Institute, Pittsburgh, USA; ${ }^{2}$ Department of Breast Medical Oncology, Morgan Welch Inflammatory \\ Breast Cancer Research Program and Clinic, University of Texas, M. D. Anderson Cancer Center, Houston, USA. \\ Email: *ralvarez@mdanderson.org
}

Received May $31^{\text {st }}, 2013$; revised July $1^{\text {st }}, 2013$; accepted July $10^{\text {th }}, 2013$

Copyright (C) 2013 José Pablo Leone, Ricardo H. Álvarez. This is an open access article distributed under the Creative Commons Attribution License, which permits unrestricted use, distribution, and reproduction in any medium, provided the original work is properly cited.

\begin{abstract}
The development of resistance to chemotherapy, endocrine therapy and anti HER2 agents in breast cancer is an important and common problem that impacts in the management of patients, particularly in the metastatic setting. This resistance has been explained in part by the activation of signal transduction pathways, including the PI3K/AKT/mTOR. The blockade with mTOR inhibitors such as everolimus is a new target agent for therapy that attempts to enhance treatment efficacy and restore tumor sensitivity. In this review article, we present the data about the use of everolimus for the treatment of breast cancer in all tumor phenotypes. Future studies that evaluate biomarkers for treatment response are needed to identify the specific populations that have the highest benefit of this new targeted therapy.
\end{abstract}

Keywords: Advanced Breast Cancer; Everolimus; mTOR Inhibitors

\section{Introduction}

Breast cancer continues to be a very prevalent disease worldwide. In 2011, it is estimated that more than 39,000 women died of breast cancer in the United States [1].

Advances in the treatment of early-stage including screening programs for breast cancer detection and adjuvant systemic treatments for breast cancer have improved outcomes for patients. Despite these improvements, however, many women ultimately develop metastatic breast cancer (MBC), which is essentially an incurable disease. The prognosis of patients with $\mathrm{MBC}$ has changed little over the past decade; the majority of patients succumb to their disease within 2 years of diagnosis [2-4]. Intrinsic or acquired resistance to chemotherapy, endocrine therapy and anti-HER2 agents is in part responsible for the poor outcome of these patients [5]. New and novel treatments for patients with breast cancer are needed to avoid the development of metastatic disease and improve survival of patients with $\mathrm{MBC}$, while minimizing toxicity.

\section{Biology of the PI3K/AKT/mTOR Pathway}

The mammalian target of rapamycin (mTOR) is a serinethreonine protein kinase that regulates cell metabolism, proliferation, survival, migration and apoptosis [6-8]. The

${ }^{*}$ Corresponding author.
mTOR belongs to the phosphatidylinositol triphosphatekinase (PI3K)-protein kinase B (AKT) signaling pathway (Figure 1) $[6,9]$. This pathway promotes translational changes through several downstream cascades $[8,10]$. It is activated when a growth factor binds to its tyrosine kinase receptor such as the insulin like growth factor 1 receptor or the human epidermal growth factor receptor (HER). PI3K in turn activates AKT by phosphorilation and AKT regulates mTOR which is involved in the final part of the signaling.

Dysregulation of this pathway, specifically upregulation of mTOR, has been associated with many types of cancer, including breast cancer [7]. Along with the upregulation of mTOR, there is also over expression of the growth factor receptor and loss of phosphatase and tensin homolog (PTEN), which is a tumor suppressor gene and an inhibitor of the mTOR pathway [6]. These mechanisms promote cell proliferation and survival [10].

Breast cancer has been associated with mutations in the PI3K gene and PTEN loss of function [11]. The latter has also been shown to be a marker of poor prognosis in patients with estrogen receptor (ER) positive breast cancer treated with tamoxifen [12].

The activation of the PI3K/AKT/mTOR pathway has a role in the development of resistance to chemotherapy, endocrine therapy and anti-HER2 agents [10,13-17]. This novel concept prompted the use of mTOR inhibitors in 


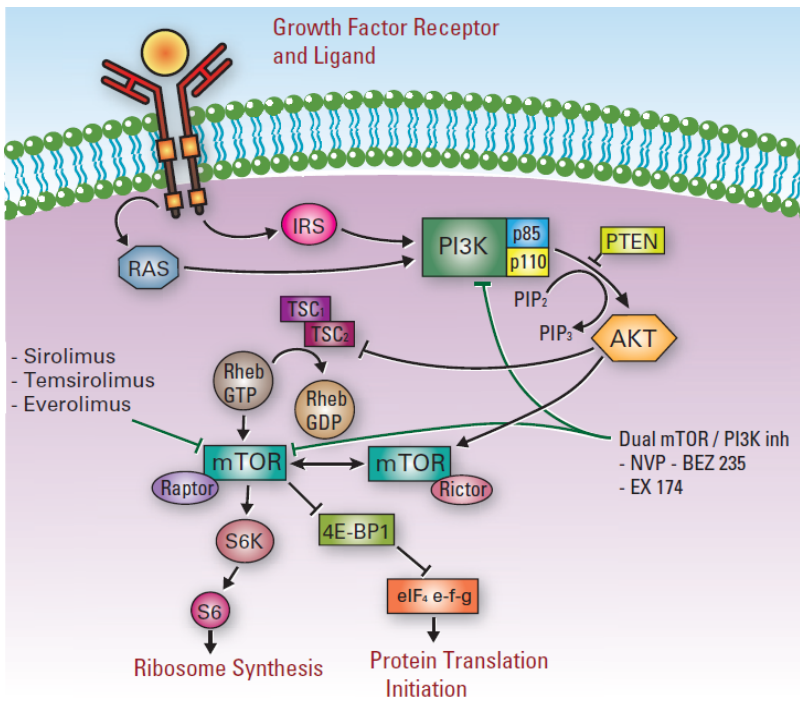

Figure 1. The mammalian target of rapamycin (mTOR) signal network. mTOR is a highly conserved pathway that regulates cell proliferation and metabolism in response to environmental factors. The growth factor receptor is linked with $\mathrm{mTOR}$ signaling via the phosphatidylinositol-3-kinase (PI3K)/Akt family. PTEN plays an important role in this pathway; loss of PTEN function through mutation, deletion, or epigenetic silencing results in increased activation of Akt and mTOR. The mTOR proteins regulate activities of the translational regulators 4E-BP1 and p70S6 kinase (S6K). mTOR antagonists have been developed to inhibit mTORC1 (raptor).

combination with the above mentioned therapies in an attempt to enhance efficacy and reverse tumor resistance.

\section{Everolimus}

Finding the most appropriate mTOR agent to use in the management of breast cancer has been a topic of recent extensive research. Everolimus derivate of sirolimus and is a strong oral mTOR inhibitor. It inhibits mTOR by binding to the FK506 binding protein 12 (FKBP-12) and phosphorylating one of the mTOR substrates, the P70 S6 ribosomal protein kinase. This complex inhibits protein synthesis and cell proliferation. It also blocks angiogenesis by decreasing the activity of vascular endothelial growth factor (VEGF) [18].

Everolimus has a rapid but moderate absorption through the gastrointestinal tract with peak concentrations after 1 to 3 hours and a bioavailability of $30 \%$. It is $74 \%$ protein bound and is metabolized in the liver via CYP3A4 and $\mathrm{P}$-glycoprotein. The excretion is mainly fecal with a half life of 30 hours [19].

Currently, everolimus has been approved by the Food Drug Administration (FDA) for the use in patients with unresectable pancreatic neuroendocrine, metastatic renal cell carcinoma after failure to sunitinib or sorafenib, and also was FDA granted for the treatment of angiomyoli- poma, tuberous sclerosis and subependymal giant cell astrocytoma. Most recently, everolimus was approved in combination with exemestane for the treatment of postmenopausal patients with metastatic breast cancer that progressed to treatment with anastrozole or letrozole.

The initial studies with mTOR inhibitors as single agent in patients with solid tumors demonstrated a clinical benefit in less than $10 \%$ of the patients [20]. A larger phase I study showed benefit in $17 \%$ of patients of which almost a third had renal cell cancer [21].

The use of mTORs inhibitors in breast cancer in combination with anti-hormone agents demonstrated some confounding data. A phase III study evaluating temsirolimus in addition to letrozole in locally advanced or metastatic breast cancer showed no improvement in progression free survival (PFS) or objective response rate (ORR) [22]. Everolimus, however, on a phase II study combined with tamoxifen demonstrated increased clinical benefit, PFS and overall survival (OS) [23].

\section{Everolimus in Combination with Endocrine Therapy}

Endocrine therapy has been a very effective treatment in patients with ER positive tumors; however resistance to this therapy in the metastatic setting is a relevant problem. One of the mechanisms of resistance is related to the $\mathrm{PI} 3 \mathrm{~K} / \mathrm{AKT} / \mathrm{mTOR}$ pathway activation, and therefore everolimus has been proposed to restore sensitivity. Table 1 summarizes multiple phase I-III studies of everolimus with endocrine therapy in the setting of ER positive metastatic breast cancer.

A phase I study evaluated everolimus 5 or $10 \mathrm{mg}$ daily in addition to letrozole $2.5 \mathrm{mg}$ daily. A total of $18 \mathrm{pa}-$ tients were evaluated, one had a complete response that lasted 22 months and another patient had a $28 \%$ reduction of liver metastases [24].

In a large randomized, double-blinded, phase II study, 270 postmenopausal women with palpable $(>2 \mathrm{~cm}) \mathrm{ER}$ positive tumors were treated with neoadjuvant letrozole with or without everolimus. Patients were treated for 16 weeks and biopsies were performed at baseline and at day 15 for biomarker assessment. The primary endpoint was response rate by clinical palpation, which was significantly higher in the everolimus arm (68.1\% vs $59.1 \%$, $\mathrm{p}=0.062)$. Significant reductions in progesterone recaptor and cyclin D1 occurred in both treatment groups, and large downregulation of phospho-S6 occurred only in the everolimus arm. An antiproliferative response with reduction in Ki67 occurred more frequently in the everolimus group ( $57 \%$ vs $30 \%, \mathrm{p}<0.01)$ [25].

The Tamoxifen-RAD001 (TAMRAD) study was an open-label, phase II, randomized study that evaluated tamoxifen in combination with everolimus in patients with hormone receptor positive, HER2 negative metastatic 
Table 1. Clinical studies evaluating the use of everolimus in patients with HR-positive breast cancer.

\begin{tabular}{|c|c|c|c|c|c|c|}
\hline Study & Design & $\mathbf{n}$ & Patient characteristics & Treatment & Endpoint & Results \\
\hline $\begin{array}{c}\text { Awada et al. } \\
\text { [24] }\end{array}$ & Phase I & 18 & $\begin{array}{l}\mathrm{ER}+\text {, metastatic, stable } \\
\text { or progressing after } 4 \text { or } \\
\text { more months of letrozole. }\end{array}$ & $\begin{array}{c}\text { everolimus } 5 \text { or } 10 \\
\text { mg daily with } \\
\text { letrozole } 2.5 \mathrm{mg} \\
\text { daily }\end{array}$ & $\begin{array}{l}\text { Toxicity, } \\
\text { efficacy }\end{array}$ & $\begin{array}{l}\text { CR: } 6 \% \\
\text { SD: } 50 \%\end{array}$ \\
\hline $\begin{array}{c}\text { Baselga et al. } \\
\text { [25] }\end{array}$ & $\begin{array}{l}\text { Randomized, } \\
\text { double-blinded, } \\
\text { phase II }\end{array}$ & 270 & $\begin{array}{l}\text { ER+, postmenopausal, } \\
\quad>2 \mathrm{~cm} \text {, untreated. }\end{array}$ & $\begin{array}{c}\text { Neoadjuvant } \\
\text { everolimus } 10 \mathrm{mg} / \text { day } \\
\text { with letrozole } 2.5 \mathrm{mg} / \text { day } \\
\text { vs neoadjuvant placebo } \\
\text { with letrozole } 2.5 \mathrm{mg} / \text { day }\end{array}$ & $\begin{array}{l}\text { RR by clinical } \\
\text { palpation. }\end{array}$ & $\begin{array}{l}\text { RR by clinical } \\
\text { palpation: } 68.1 \% \\
\text { vs } 59.1 \% \text {. } \\
\text { RR by ultrasound: } \\
58 \% \text { vs } 47 \%\end{array}$ \\
\hline $\begin{array}{c}\text { Bachelot et al. } \\
\text { [23] }\end{array}$ & $\begin{array}{c}\text { Randomized, } \\
\text { open-label, phase II }\end{array}$ & 111 & $\begin{array}{l}\text { HR+, HER2-, } \\
\text { postmenopausal, } \\
\text { metastatic, previously } \\
\text { treated with AI. }\end{array}$ & $\begin{array}{c}\text { Tamoxifen } 20 \mathrm{mg} / \text { day } \\
\text { with everolimus } 10 \mathrm{mg} / \text { day } \\
\text { vs Tamoxifen } 20 \mathrm{mg} / \text { day }\end{array}$ & $\begin{array}{l}\text { CBR at } \\
6 \text { months }\end{array}$ & $\begin{array}{l}\text { CBR: } 61 \% \\
\text { vs } 42 \% \\
\text { PFS: } 8.6 \text { months } \\
\text { vs } 4.5 \text { months }\end{array}$ \\
\hline $\begin{array}{l}\text { Badin et al. } \\
\quad \text { [26] }\end{array}$ & Ongoing phase II & 11 & $\begin{array}{l}\text { ER+, metastatic, } \\
\text { progressed to AI } \\
\text { within } 6 \text { months. }\end{array}$ & $\begin{array}{l}\text { everolimus } 10 \mathrm{mg} \text { daily } \\
\text { with intramuscular } \\
\text { fulvestrant } 500 \mathrm{mg} \text { on } \\
\text { day } 1,250 \mathrm{mg} \text { on days } 14 \\
\text { and } 28 \text {, and } 250 \mathrm{mg} \\
\text { monthly thereafter }\end{array}$ & $\begin{array}{l}\text { PFS } \\
\text { CBR for } \\
24 \text { weeks } \\
\text { or longer }\end{array}$ & $\begin{array}{l}\text { PFS: } 8.6 \text { months } \\
\text { CBR: } 55 \%\end{array}$ \\
\hline $\begin{array}{c}\text { Baselga et al. } \\
\text { [27] }\end{array}$ & $\begin{array}{l}\text { Randomized, } \\
\text { double-blinded, } \\
\text { phase III }\end{array}$ & 724 & $\begin{array}{c}\text { ER+, HER2-, } \\
\text { postmenopausal, } \\
\text { advanced breast cancer, } \\
\text { refractory to anastrozole } \\
\text { or letrozole. }\end{array}$ & $\begin{array}{l}\text { exemestane } 25 \mathrm{mg} \text { daily } \\
\text { with placebo vs } \\
\text { exemestane } 25 \mathrm{mg} \text { daily } \\
\text { with everolimus } 10 \mathrm{mg} \\
\text { daily }\end{array}$ & $\begin{array}{l}\text { PFS (locally } \\
\text { and centrally } \\
\text { reviewed) }\end{array}$ & $\begin{array}{l}\text { PFS by central } \\
\text { review: } 10.6 \text { months } \\
\text { vs } 4.1 \text { months } \\
\text { PFS by local review: } \\
6.9 \text { months } \\
\text { vs } 2.8 \text { months }\end{array}$ \\
\hline
\end{tabular}

AI: aromatase inhibitors; CBR: clinical benefit rate; CR: complete response; ER: estrogen receptor; HER2: human epidermal growth factor receptor 2; HR: hormone receptor; PFS: progression free survival; RR: response rate; SD: stable disease

breast cancer previously treated with aromatase inhibitors. The investigators randomized 111 patients to receive tamoxifen $20 \mathrm{mg}$ daily alone or tamoxifen $20 \mathrm{mg}$ daily with everolimus $10 \mathrm{mg}$ daily. The primary endpoint was clinical benefit rate (CBR), defined as the percentage of patients with $\mathrm{CR}$ or PR or stable disease at 6 months. CBR was observed in $61 \%$ (95\% CI $47 \%-74 \%)$ in the combination group compared with $42 \%$ (95\% CI 29\% $56 \%$ ) in the tamoxifen alone group (exploratory $\mathrm{p}=$ 0.045). The combination group also had significantly longer PFS (8.6 mo vs $4.5 \mathrm{mo}, \mathrm{p}=0.002)$ and superior OS with a hazard ratio (HR) of 0.45 (95\% CI $0.24-0.81$, exploratory $\mathrm{p}=0.007)$. Interestingly, in an exploratory subgroup analysis, the authors found that the everolimus benefit was mostly for patients with secondary hormone resistance, with a reduction in the risk of progression associated with everolimus of $54 \%$ in this subgroup (HR, 0.46 ; $95 \% \mathrm{CI}, 0.26$ to 0.83 ), which favors the proposed mechanism of reversing endocrine resistance [23].

An ongoing phase II study of patients with ER positive metastatic breast cancer who failed aromatase inhibitor therapy within 6 months, is evaluating everolimus $10 \mathrm{mg}$ daily in combination with intramuscular fulvestrant 500 $\mathrm{mg}$ on day $1250 \mathrm{mg}$ on day $14,250 \mathrm{mg}$ on day 28 , and $250 \mathrm{mg}$ monthly thereafter. The primary endpoint is PFS, and the secondary endpoints are toxicity, biomarker evaluation, ORR, and clinical benefit rate $(\mathrm{CR}+\mathrm{PR}+$ stable disease for 24 weeks or longer). Preliminary results with only 11 patients enrolled showed a median PFS of 8.6 months and a clinical benefit rate of 55\% [26].

The Breast Cancer trial of Oral Everolimus 2 (BOLERO-2) was a phase III randomized study evaluating everolimus with exemestane in patients with ER positive HER2 negative advanced breast cancer that is refractory to anastrozole or letrozole. A total of 724 patients were randomized $2: 1$ to receive exemestane $25 \mathrm{mg}$ daily with placebo or exemestane $25 \mathrm{mg}$ daily with everolimus 10 mg daily. The primary endpoint was PFS which was assessed separately by local investigators and central assessment. The median PFS by central review was 10.6 
months with everolimus and exemestane and 4.1 months with placebo and exemestane (hazard ratio, $0.36 ; 95 \% \mathrm{CI}$, 0.27 to $0.47 ; \mathrm{p}<0.001)$. The ORR was superior in the everolimus arm $(9.5 \%$ vs $0.4 \% \mathrm{p}<0.001)$. Survival data showed only 83 deaths which represented $10.7 \%$ in the everolimus arm vs $13 \%$ in the control group [27]. Due to the results of this study, the FDA approved the use of everolimus combined with exemestane on July 20, 2012 for postmenopausal women with metastatic breast cancer that had progressed to anastrozole or letrozole.

\section{HER2 Positive Disease}

Amplification or overexpression of the HER2 gene is found in around $15 \%-20 \%$ of breast cancers [28]. Standard treatments in the adjuvant setting include the utilization of trastuzumab-containing regimens for up to 1 year [29]. Most recently, the novel agent pertuzumab was approved for the use in the metastatic setting in combination with docetaxel and trastuzumab [30].

A number of phase I and II studies have been con- ducted evaluating the efficacy of everolimus in patients with HER2-positive metastatic breast cancer. Their results are summarized in Table 2.

A phase Ib study evaluated 33 patients with metastatic breast cancer pretreated with trastuzumab who received everolimus $5 \mathrm{mg}$ daily, $10 \mathrm{mg}$ daily or $30 \mathrm{mg}$ per week in combination with paclitaxel $80 \mathrm{mg} / \mathrm{m}^{2}$ on days 1,8 and 15 every 4 weeks and trastuzumab $2 \mathrm{mg} / \mathrm{kg}$ weekly. There were 27 patients with measurable disease that were evaluated for efficacy, of which $44 \%$ had ORR. The median PFS was 34 weeks, two patients had CR, 10 patients had PR and 13 patients had stable disease [31].

Subsequently, a follow-up phase II study was performed on patients with metastatic disease resistant to taxanes and trastuzumab [32]. Patients were treated with everolimus $10 \mathrm{mg}$ daily and paclitaxel and trastuzumab in similar doses to the phase $\mathrm{Ib}$ study previously mentioned. From a total of 48 evaluable patients, $9(19 \%)$ had PR and $30(62 \%)$ had stable disease. The median PFS was 26 weeks.

Table 2. Clinical studies evaluating the use of everolimus in patients with HER2-positive breast cancer.

\begin{tabular}{|c|c|c|c|c|c|c|}
\hline Study & Design & $\mathbf{n}$ & $\begin{array}{c}\text { Patient } \\
\text { characteristics }\end{array}$ & Treatment & Endpoint & Results \\
\hline $\begin{array}{l}\text { Andre } \\
\text { et al. [31] }\end{array}$ & Phase Ib & 33 & $\begin{array}{c}\text { HER2+, metastatic, } \\
\text { pretreated with } \\
\text { trastuzumab }\end{array}$ & $\begin{array}{c}\text { everolimus } 5 \mathrm{mg} \\
\text { daily, } 10 \mathrm{mg} \\
\text { daily or } 30 \mathrm{mg} \text { per week } \\
\text { with paclitaxel } 80 \mathrm{mg} / \mathrm{m}^{2} \\
\text { on days } 1,8 \text { and } 15 \text { every } \\
4 \text { weeks and } \\
\text { trastuzumab } 2 \mathrm{mg} / \mathrm{kg} \\
\text { weekly }\end{array}$ & $\begin{array}{l}\text { Toxicity, } \\
\text { efficacy }\end{array}$ & $\begin{array}{c}17 \text { patients had grade } \\
3 \text { - } 4 \text { neutropenia. } \\
\text { ORR: } 44 \% \\
\text { PFS: } 34 \text { weeks. }\end{array}$ \\
\hline $\begin{array}{l}\text { Jerusalem } \\
\text { et al. [33] }\end{array}$ & Phase Ib & 50 & $\begin{array}{l}\text { HER2+, metastatic, } \\
\text { progressed after } \\
\text { trastuzumab }\end{array}$ & $\begin{array}{c}\text { everolimus } 5 \mathrm{mg} \text { daily, } \\
20 \mathrm{mg} \text { weekly or } \\
30 \mathrm{mg} \text { weekly with } \\
\text { trastuzumab } \\
2 \mathrm{mg} / \mathrm{kg} \text { weekly and } \\
\text { vinorelbine } \\
25 \mathrm{mg} / \mathrm{m}^{2} \text { on } \\
\text { days } 1 \text { and } 8 \text { every } 3 \text { weeks }\end{array}$ & $\begin{array}{l}\text { Toxicity, } \\
\text { efficacy }\end{array}$ & $\begin{array}{c}14 \text { patients had grade } \\
3 \text { - } 4 \text { neutropenia. } \\
\text { ORR: } 19.1 \% \\
\text { CBR: } 54 \% \\
\text { PFS: } 30.7 \text { weeks. }\end{array}$ \\
\hline $\begin{array}{l}\text { Morrow } \\
\text { et al. [36] }\end{array}$ & Phase I/II & 47 & $\begin{array}{c}\text { HER2+, metastatic, } \\
\text { progressed after } \\
\text { trastuzumab }\end{array}$ & $\begin{array}{c}\text { Trastuzumab } 6 \mathrm{mg} / \mathrm{kg} \\
\text { every } 3 \text { weeks } \\
\text { with everolimus } 5 \\
\text { or } 10 \mathrm{mg} \text { daily }\end{array}$ & $\begin{array}{l}\text { Toxicity, } \\
\text { efficacy }\end{array}$ & $\begin{array}{c}\text { PR: } 15 \% \\
\text { SD: } 19 \% \\
\text { PFS: } 4.1 \text { months }\end{array}$ \\
\hline $\begin{array}{c}\text { Dalenc } \\
\text { et al. [32] }\end{array}$ & Phase II & 48 & $\begin{array}{l}\text { HER2+, metastatic, } \\
\text { resistant to taxanes } \\
\text { and trastuzumab. }\end{array}$ & $\begin{array}{c}\text { everolimus } 10 \mathrm{mg} \text { daily } \\
\text { with paclitaxel } \\
80 \mathrm{mg} / \mathrm{m}^{2} \text { on days } \\
1,8 \text { and } 15 \text { every } 4 \\
\text { weeks and trastuzumab } \\
2 \mathrm{mg} / \mathrm{kg} \text { weekly }\end{array}$ & Efficacy & $\begin{array}{c}\text { PR: } 19 \% \\
\text { SD: } 62 \% \\
\text { PD: } 19 \% \\
\text { PFS: } 26 \text { weeks. }\end{array}$ \\
\hline
\end{tabular}

CBR: clinical benefit rate; HER2: human epidermal growth factor receptor 2; ORR: overall response rate; PFS: progression free survival; PD: progression of disease; PR: partial response; SD: stable disease. 
Another phase Ib study evaluated everolimus daily or weekly in patients with HER2 positive metastatic breast cancer who progressed after trastuzumab. Patients were administered everolimus $5 \mathrm{mg}$ daily, $20 \mathrm{mg}$ weekly or $30 \mathrm{mg}$ weekly in combination with trastuzumab $2 \mathrm{mg} / \mathrm{kg}$ weekly and vinorelbine $25 \mathrm{mg} / \mathrm{m}^{2}$ on days 1 and 8 every 3 weeks [33]. Median PFS was 30.7 weeks. A total of 47 patients were evaluated of which $19 \%$ had objective response and $54 \%$ had clinical benefit (CR + PR + stable disease for at least 24 weeks). The study had an extension phase in which patients were allowed to continue everolimus whereas vinorelbine could be stopped at the investigator's discretion [34]. Two patients had CR, one had PR and the median PFS was 41 weeks.

With the information from the above mentioned studies, a pooled analysis was conducted to assess the efficacy of everolimus in patients previously treated with lapatinib. A total of 101 patients were evaluated with an ORR of $21 \%$ for patients who received lapatinib compared with $29 \%$ for those that did not receive lapatinib [35]. The disease control rate was $88 \%$ and $81 \%$ respectively. The mean PFS was 29 and 36.1 weeks respectively. This study showed that everolimus combined with trastuzumab and chemotherapy was still efficacious even in patients pretreated with lapatinib, which formulated the possible role of everolimus in the reversal of resistance to anti-HER2 agents.

Trastuzumab resistance has been linked to activation of the PI3K/AKT/mTOR pathway. For this reason, a phase I/II study was conducted on patients with metastatic breast cancer who had progressed to trastuzumab [36]. This was a pooled analysis of 47 patients from two concurrent trials, patient received trastuzumab $6 \mathrm{mg} / \mathrm{kg}$ every 3 weeks in combination with everolimus 5 or $10 \mathrm{mg}$ daily. The median PFS was 4.1 months. PR was seen in 7 patients $(15 \%)$ and stable disease in 9 patients (19\%). Interestingly, patients with PTEN loss demonstrated decreased overall survival $(p=0.048)$. However, PFS was not affected by PTEN loss.

\section{Everolimus with Chemotherapy}

Several studies have been conducted in patients with tumors that are HER2 negative, ER negative or triple negative (ER negative, PR negative, HER2 negative). These studies used the combination of everolimus with chemotherapy.

In an open-label phase Ib study, everolimus in three dose escalation levels $(20,25$, and $30 \mathrm{mg} / \mathrm{wk})$ was given with cisplatin $25 \mathrm{mg} / \mathrm{m}^{2}$ and paclitaxel $80 \mathrm{mg} / \mathrm{m}^{2}$ weekly for 3 weeks of a 4 weeks cycle. A total of 18 patients were evaluated, one had CR. PR and SD were seen in 5 and 9 patients respectively. Three patients progressed. The median PFS was 6 months [37].

A randomized phase II study evaluated patients with early stage or locally advanced triple negative breast cancer [38]. Patients were treated with neoadjuvant weekly paclitaxel $80 \mathrm{mg} / \mathrm{m}^{2}$ alone or in combination with everolimus $30 \mathrm{mg}$ weekly for 12 weeks followed by 5 -fluorouracil $500 \mathrm{mg} / \mathrm{m}^{2}$, epirubicin $100 \mathrm{mg} / \mathrm{m}^{2}$ and cyclophosphamide $500 \mathrm{mg} / \mathrm{m}^{2}$ every 3 weeks for 4 cycles. A total of 50 patients were randomized. The 12 week response rate by ultrasound was $29.6 \%$ in the comparison group vs $47.8 \%$ in the experimental arm $(p=0.15)$. There was no significant difference between pathologic CR rates between the 2 groups. The therapy was well tolerated and further studies should be conducted to continue exploring this option in this high risk subset of patients.

\section{Future Perspectives}

Multiple studies are currently evaluating the combination of everolimus with chemotherapy and targeted-therapy for breast cancer. Table 3 summarizes these trials. The research spectrum is very broad and embraces all settings from neoadjuvant to metastatic, however many of the studies are having difficulties with patient recruitment. The research questions that these studies intend to address are of significant relevance to the clinical practice and therefore enrollment should be emphasized to all patients.

\section{Conclusions}

The inhibition of the mTOR pathway is a new and excit ing option for the treatment of patients with breast cancer. The results of the clinical studies we discussed are very encouraging. In metastatic ER-positive breast cancer there is now a potential role for the combination of everolimus with steroidal aromatase inhibitors (AI) in patients previously exposed to non-steroidal AI. The National Comprehensive Cancer Network (NCCN) guidelines support this strategy for patients with endocrine therapy resistant breast cancer. The improvement of the PFS is associated with more toxicity and the cost increase of the regimen. There are at least two ongoing Phase III studies using everolimus in the adjuvant setting.

In patients with HER2-positive disease, results from early clinical data on combination with everolimus plus anti-HER2 therapies are encouraging. However, the results from larger studies are not available yet.

Although these are promising results, many patients still do not respond to these therapies. Important questions remain unanswered. Are there specific subgroups who receive greater benefit from everolimus? Is there a relationship between PIK3CA mutation and efficacy? Further studies with the inclusion of biomarker analysis for treatment response are needed to identify the subgroup of patients that benefit the most from the blockade of the mTOR pathway. 
Table 3. Clinical studies evaluating the use of everolimus in combination with targeted therapy in advanced breast cancer.

\begin{tabular}{|c|c|c|c|c|c|}
\hline Trial ID/Phase & Sponsor & Title & Regimen & Endpoint & $\begin{array}{l}\text { Estimated } \\
\text { enrollment }\end{array}$ \\
\hline $\begin{array}{l}\text { NCT01743560 } \\
\text { Phase IV }\end{array}$ & $\begin{array}{c}\text { Novartis } \\
\text { Pharmaceuticals }\end{array}$ & $\begin{array}{c}\text { A Phase IV Multicentre, Open Label Study } \\
\text { of Postmenopausal Women with } \\
\text { Oestrogen Receptor Positive Locally } \\
\text { Advanced or Metastatic Breast Cancer } \\
\text { Treated with Everolimus (RAD001) in } \\
\text { Combination with Exemestane, with } \\
\text { Exploratory Epigenetic Marker Analysis }\end{array}$ & $\begin{array}{c}\text { Everolimus } 10 \mathrm{mg} \\
\text { daily and exemestane } \\
25 \mathrm{mg} \text { daily }\end{array}$ & $\begin{array}{l}\text { ORR } \\
\text { PFS } \\
\text { OS } \\
\text { QOL }\end{array}$ & $\begin{array}{l}50 \\
\text { Not yet open }\end{array}$ \\
\hline $\begin{array}{c}\text { NCT01272141 } \\
\text { Phase II }\end{array}$ & $\begin{array}{c}\text { Emory } \\
\text { University }\end{array}$ & $\begin{array}{l}\text { Phase II Trial of Lapatinib in } \\
\text { Combination with Everolimus in } \\
\text { Triple Negative Metastatic or } \\
\text { Locally Advanced Breast Cancer }\end{array}$ & $\begin{array}{c}\text { Lapatinib } 1250 \mathrm{mg} \\
\text { daily and everolimus } \\
5 \mathrm{mg} \text { daily }\end{array}$ & $\begin{array}{c}\text { ORR } \\
\text { Safety } \\
\text { and toxicity }\end{array}$ & $\begin{array}{c}43 \\
\text { Recruiting }\end{array}$ \\
\hline $\begin{array}{c}\text { NCT01520103 } \\
\text { Phase II }\end{array}$ & AIO-Studien-gGmbH & $\begin{array}{l}\text { Randomized Phase II Study to } \\
\text { Compare Vinorelbine In Combination } \\
\text { With the mTOR Inhibitor Everolimus vs. } \\
\text { Vinorelbin Monotherapy for Second-line } \\
\text { Treatment in Advanced Breast Cancer }\end{array}$ & $\begin{array}{l}\text { Vinorelbine } 25 \mathrm{mg} / \mathrm{m}^{2} \\
\text { days } 1,8,15 \text { with or } \\
\text { without Everolimus } \\
5 \mathrm{mg} \text { daily }\end{array}$ & $\begin{array}{l}\text { PFS } \\
\text { Safety } \\
\text { OS } \\
\text { RR }\end{array}$ & $\begin{array}{c}166 \\
\text { Recruiting }\end{array}$ \\
\hline $\begin{array}{l}\text { NCT01305941 } \\
\text { Phase II }\end{array}$ & $\begin{array}{l}\text { UNC Lineberger } \\
\text { Comprehensive } \\
\text { Cancer Center }\end{array}$ & $\begin{array}{c}\text { A Phase II Study Evaluating the } \\
\text { Efficacy and Tolerability of } \\
\text { Everolimus (RAD001) In Combination } \\
\text { with Trastuzumab and Vinorelbine in } \\
\text { the Treatment of Progressive } \\
\text { HER2-Positive Breast Cancer } \\
\text { Brain Metastases }\end{array}$ & $\begin{array}{c}\text { Everolimus } 5 \mathrm{mg} \text { daily } \\
+ \text { vinorelbine } 25 \mathrm{mg} / \mathrm{m}^{2} \\
\text { weekly }+ \text { trastuzumab } 2 \\
\mathrm{mg} / \mathrm{kg} \text { weekly }\end{array}$ & $\begin{array}{l}\text { Intracranial } \\
\text { RR } \\
\text { Extracranial } \\
\text { RR } \\
\text { Toxicity }\end{array}$ & $\begin{array}{c}35 \\
\text { Recruiting }\end{array}$ \\
\hline $\begin{array}{l}\text { NCT01626222 } \\
\text { Phase III }\end{array}$ & $\begin{array}{c}\text { Novartis } \\
\text { Pharmaceuticals }\end{array}$ & $\begin{array}{l}\text { A Phase IIIB, Multi-Center, Open } \\
\text { Label Study for Postmenopausal Women } \\
\text { With Estrogen Receptor Positive Locally } \\
\text { Advanced or Metastatic Breast Cancer } \\
\text { Treated with Everolimus (RAD001) in } \\
\text { Combination with Exemestane: } \\
\text { 4EVER-Efficacy, Safety, Health } \\
\text { Economics, Translational Research }\end{array}$ & $\begin{array}{l}\text { Everolimus } 10 \mathrm{mg} \text { daily } \\
\text { and exemestane } \\
25 \mathrm{mg} \text { daily }\end{array}$ & $\begin{array}{l}\text { ORR } \\
\text { PFS } \\
\text { OS } \\
\text { Safety } \\
\text { QOL }\end{array}$ & $\begin{array}{c}300 \\
\text { Recruiting }\end{array}$ \\
\hline $\begin{array}{c}\text { NCT00876395 } \\
\text { Phase III }\end{array}$ & $\begin{array}{c}\text { Novartis } \\
\text { Pharmaceuticals }\end{array}$ & $\begin{array}{l}\text { A Randomized Phase III, Double-Blind, } \\
\text { Placebo-Controlled Multicenter Trial of } \\
\text { Everolimus in Combination with } \\
\text { Trastuzumab and Paclitaxel, as First Line } \\
\text { Therapy in Women With HER2 Positive } \\
\text { Locally Advanced or Metastatic } \\
\text { Breast Cancer }\end{array}$ & $\begin{array}{c}\text { Everolimus } 10 \mathrm{mg} \\
\text { daily }+ \text { paclitaxel } \\
80 \mathrm{mg} / \mathrm{m}^{2} \text { days } \\
1,8,15+\text { trastuzumab } \\
2 \mathrm{mg} / \mathrm{kg} \text { days } 1,8,15,22 \\
\text { vs Placebo }+ \text { paclitaxel } \\
80 \mathrm{mg} / \mathrm{m}^{2} \text { days } 1,8,15 \\
+ \text { trastuzumab } 2 \mathrm{mg} / \mathrm{kg} \\
\text { days } 1,8,15,22\end{array}$ & $\begin{array}{l}\text { PFS } \\
\text { OS } \\
\text { ORR } \\
\text { CBR }\end{array}$ & $\begin{array}{l}719 \\
\text { Not recruiting }\end{array}$ \\
\hline $\begin{array}{l}\text { NCT01007942 } \\
\text { Phase III }\end{array}$ & $\begin{array}{c}\text { Novartis } \\
\text { Pharmaceuticals }\end{array}$ & $\begin{array}{c}\text { A Randomized Phase III, Double-blind, } \\
\text { Placebo-controlled Multicenter Trial } \\
\text { of Daily Everolimus in Combination } \\
\text { With Trastuzumab and Vinorelbine, } \\
\text { in Pretreated Women with HER2/Neu } \\
\text { Over-Expressing Locally Advanced or } \\
\text { Metastatic Breast Cancer }\end{array}$ & $\begin{array}{l}\text { Everolimus + vinorelbine } \\
+ \text { trastuzumab vs placebo } \\
+ \text { vinorelbine }+ \text { trastuzumab. } \\
\text { Doses not reported. }\end{array}$ & $\begin{array}{l}\text { PFS } \\
\text { OS } \\
\text { ORR } \\
\text { Patient } \\
\text { reported } \\
\text { outcomes } \\
\text { CBR }\end{array}$ & $\begin{array}{l}569 \\
\text { Not recruiting }\end{array}$ \\
\hline
\end{tabular}




\begin{tabular}{|c|c|c|c|c|c|}
\hline $\begin{array}{c}\text { NCT00567554 } \\
\text { Phase III }\end{array}$ & $\begin{array}{c}\text { German } \\
\text { Breast Group }\end{array}$ & $\begin{array}{l}\text { A Phase III Trials Program Exploring } \\
\text { the Integration of Bevacizumab, } \\
\text { Everolimus (RAD001), and Lapatinib } \\
\text { into Current Neoadjuvant Chemotherapy } \\
\text { Regimes for Primary Breast Cancer }\end{array}$ & $\begin{array}{c}\text { Epirubicin }+ \text { cyclophosphamide } \\
+ \text { docetaxel with or without } \\
\text { bevacizumab vs paclitaxel } \\
\text { with or without everolimus } \\
\text { vs epirubicin }+ \\
\text { cyclophosphamide } \\
+ \text { docetaxel with } \\
\text { trastuzumab or lapatinib }\end{array}$ & $\begin{array}{l}\text { pCR } \\
\text { Toxicity } \\
\text { RR } \\
\text { DFS } \\
\text { OS }\end{array}$ & $\begin{array}{l}2600 \\
\text { Not recruiting }\end{array}$ \\
\hline $\begin{array}{c}\text { NCT00570921 } \\
\text { Phase II }\end{array}$ & $\begin{array}{l}\text { University } \\
\text { of Kentucky }\end{array}$ & $\begin{array}{c}\text { A Phase II Study of Combined } \\
\text { Fulvestrant (Faslodex) and RAD001 } \\
\text { (Everolimus) in Advanced/Metastatic } \\
\text { Breast Cancer after Aromatase } \\
\text { Inhibitor Failure }\end{array}$ & $\begin{array}{l}\text { Everolimus } 10 \mathrm{mg} \text { daily } \\
+ \text { fulvestrant } 500 \mathrm{mg} \\
\text { day } 1,14,28\end{array}$ & $\begin{array}{c}\text { TTP } \\
\text { RR } \\
\text { CBR } \\
\text { Toxicity }\end{array}$ & $\begin{array}{c}44 \\
\text { Recruiting }\end{array}$ \\
\hline $\begin{array}{l}\text { NCT00863655 } \\
\text { Phase III }\end{array}$ & $\begin{array}{c}\text { Novartis } \\
\text { Pharmaceuticals }\end{array}$ & $\begin{array}{c}\text { A Randomized Double-Blind, } \\
\text { Placebo-Controlled Study of Everolimus } \\
\text { in Combination with Exemestane in the } \\
\text { Treatment of Postmenopausal Women } \\
\text { with Estrogen Receptor Positive Locally } \\
\text { Advanced or Metastatic Breast Cancer } \\
\text { Who Are Refractory to Letrozole } \\
\text { or Anastrozole }\end{array}$ & $\begin{array}{l}\text { Everolimus } 10 \mathrm{mg} \text { daily } \\
+ \text { exemestane } 25 \mathrm{mg} \text { daily } \\
\text { vs placebo }+ \text { exemestane } \\
25 \mathrm{mg} \text { daily }\end{array}$ & $\begin{array}{l}\text { PFS } \\
\text { OS } \\
\text { ORR } \\
\text { Toxicity } \\
\text { QOL }\end{array}$ & $\begin{array}{l}724 \\
\text { Not recruiting }\end{array}$ \\
\hline $\begin{array}{c}\text { NCT00912340 } \\
\text { Phase II }\end{array}$ & $\begin{array}{l}\text { Emory } \\
\text { University }\end{array}$ & $\begin{array}{c}\text { Randomized Phase II Trial of } \\
\text { Trastuzumab or Everolimus in } \\
\text { Hormone-Refractory Metastatic } \\
\text { Breast Cancer }\end{array}$ & $\begin{array}{l}\text { Trastuzumab } 6 \mathrm{mg} / \mathrm{kg} \\
\text { every } 3 \text { weeks }(8 \mathrm{mg} / \mathrm{kg} \\
\text { loading dose }) \mathrm{vs} \\
\text { everolimus } 10 \mathrm{mg} \text { daily }\end{array}$ & $\begin{array}{l}\text { RR } \\
\text { CBR } \\
\text { PFS }\end{array}$ & $\begin{array}{c}80 \\
\text { Recruiting }\end{array}$ \\
\hline $\begin{array}{c}\text { NCT00930930 } \\
\text { Phase II }\end{array}$ & $\begin{array}{l}\text { Vanderbilt-Ingram } \\
\text { Cancer Center }\end{array}$ & $\begin{array}{l}\text { A Phase II Neo-Adjuvant Study of } \\
\text { Cisplatin, Paclitaxel With or Without } \\
\text { RAD001 in Patients with Triple-negative } \\
\text { Locally Advanced Breast Cancer }\end{array}$ & $\begin{array}{c}\text { Cisplatin } 25 \mathrm{mg} / \mathrm{m}^{2} \text { weekly } \\
+ \text { everolimus } 5 \mathrm{mg} \text { daily } \\
\text { for } 1 \text { week followed by } \\
\text { cisplatin } 25 \mathrm{mg} / \mathrm{m}^{2}+ \\
\text { paclitaxel } 80 \mathrm{mg} / \mathrm{m}^{2} \\
\text { weekly + everolimus } 5 \mathrm{mg} \\
\text { daily for } 11 \text { weeks vs } \\
\text { cisplatin } 25 \mathrm{mg} / \mathrm{m}^{2} \text { weekly } \\
+ \text { placebo daily for } 1 \text { week } \\
\text { followed by cisplatin } 25 \mathrm{mg} / \mathrm{m}^{2} \\
+ \text { paclitaxel } 80 \mathrm{mg} / \mathrm{m}^{2} \\
\text { weekly }+ \text { placebo daily } \\
\text { for } 11 \text { weeks }\end{array}$ & $\begin{array}{l}\text { pCR } \\
\text { Number } \\
\text { of breast } \\
\text { conservation } \\
\text { surgery } \\
\text { Clinical } \\
\text { response }\end{array}$ & $\begin{array}{c}145 \\
\text { Recruiting }\end{array}$ \\
\hline $\begin{array}{l}\text { NCT00317720 } \\
\text { Phase I-II }\end{array}$ & $\begin{array}{l}\text { M.D. Anderson } \\
\text { Cancer Center }\end{array}$ & $\begin{array}{c}\text { Phase I-II Study of Trastuzumab in } \\
\text { Combination with RAD001 in Patients } \\
\text { with HER-2 Overexpressing, } \\
\text { PTEN-Deficient Metastatic Breast Cancer } \\
\text { Progressing on Trastuzumab-Based Therapy }\end{array}$ & $\begin{array}{c}\text { Trastuzumab loading } \\
\text { dose } 8 \mathrm{mg} / \mathrm{kg} \text { daily; } \\
\text { maintenance dose } 6 \mathrm{mg} / \mathrm{kg} \\
\text { every } 21 \text { days }+ \text { everolimus } \\
10 \mathrm{mg} \text { daily }\end{array}$ & $\begin{array}{l}\text { Optimal dose } \\
\text { ORR } \\
\text { Biomarkers } \\
\text { of response }\end{array}$ & $\begin{array}{l}47 \\
\text { Not recruiting }\end{array}$ \\
\hline $\begin{array}{l}\text { NCT00934895 } \\
\text { Phase I-II }\end{array}$ & $\begin{array}{c}\text { University of } \\
\text { Medicine and } \\
\text { Dentistry New Jersey }\end{array}$ & $\begin{array}{c}\text { Phase I/II Study of Weekly } \\
\text { Abraxane and RAD001 in Women } \\
\text { With Locally Advanced or Metastatic } \\
\text { Breast Cancer. A Study of the Cancer } \\
\text { Institute of New Jersey Oncology } \\
\text { Group (CINJOG) }\end{array}$ & $\begin{array}{c}\text { Abraxane }+ \text { everolimus } \\
5 \mathrm{mg} \text { daily with } \\
\text { escalation protocol }\end{array}$ & $\begin{array}{l}\text { Optimal dose } \\
\text { ORR } \\
\text { Toxicity }\end{array}$ & $\begin{array}{c}72 \\
\text { Recruiting }\end{array}$ \\
\hline $\begin{array}{l}\text { NCT01627067 } \\
\text { Phase II }\end{array}$ & $\begin{array}{l}\text { M.D. Anderson } \\
\text { Cancer Center }\end{array}$ & $\begin{array}{l}\text { Circulating FGF21 Levels and } \\
\text { Efficacy of Exemestane, Everolimus } \\
\text { and Metformin in Postmenopausal } \\
\text { Women with Hormone Receptor } \\
\text { Positive Metastatic Breast Cancer } \\
\text { and BMI }>/=25\end{array}$ & $\begin{array}{l}\text { Exemestane } 25 \mathrm{mg} \text { daily } \\
\text { + everolimus } 10 \mathrm{mg} \text { daily } \\
\quad+\text { metformin } 500 \mathrm{mg} \\
\text { daily with escalation to } \\
1000 \mathrm{mg} \text { twice daily }\end{array}$ & PFS & $\begin{array}{c}40 \\
\text { Recruiting }\end{array}$ \\
\hline $\begin{array}{c}\text { NCT01127763 } \\
\text { Phase II }\end{array}$ & $\begin{array}{l}\text { New York } \\
\text { University School } \\
\text { of Medicine }\end{array}$ & $\begin{array}{c}\text { Phase II Trial of RAD001 Plus } \\
\text { Carboplatin in Patients With } \\
\text { Triple-Negative Metastatic } \\
\text { Breast Cancer }\end{array}$ & $\begin{array}{c}\text { Carboplatin AUC } 4 \text { every } \\
\text { three weeks }+ \text { everolimus } \\
5 \mathrm{mg} \text { daily }\end{array}$ & $\begin{array}{l}\text { ORR } \\
\text { Toxicity } \\
\text { PFS }\end{array}$ & $\begin{array}{l}28 \\
\text { Not recruiting }\end{array}$ \\
\hline
\end{tabular}




\begin{tabular}{|c|c|c|c|c|c|}
\hline \multicolumn{6}{|l|}{ Continued } \\
\hline $\begin{array}{c}\text { NCT01283789 } \\
\text { Phase II }\end{array}$ & $\begin{array}{l}\text { University } \\
\text { of Kansas }\end{array}$ & $\begin{array}{l}\text { Phase II Trial of Lapatinib and } \\
\text { RAD-001 for HER2 Positive } \\
\text { Metastatic Breast Cancer }\end{array}$ & $\begin{array}{l}\text { Everolimus } 5 \mathrm{mg} \text { daily } \\
\text { + lapatinib } 1250 \mathrm{mg} \text { daily }\end{array}$ & $\begin{array}{l}\text { ORR } \\
\text { PFS } \\
\text { CBR }\end{array}$ & $\begin{array}{c}45 \\
\text { Recruiting }\end{array}$ \\
\hline $\begin{array}{c}\text { NCT01088893 } \\
\text { Phase II }\end{array}$ & $\begin{array}{l}\text { Organisation for } \\
\text { Oncology and } \\
\text { Translational } \\
\text { Research }\end{array}$ & $\begin{array}{l}\text { A Randomized Study of mTOR } \\
\text { Inhibition by RAD001 (Everolimus) } \\
\text { in Invasive Breast Cancer Patients } \\
\text { After Pre-Operative Use of Anthracycline } \\
\text { and/or Taxane-Based Chemotherapy }\end{array}$ & $\begin{array}{l}\text { Everolimus } 10 \mathrm{mg} \text { daily } \\
\text { for } 3 \text { weeks, } 1 \text { week } \\
\text { after completion of } \\
\text { neoadjuvant treatment } \\
\text { and before surgery }\end{array}$ & $\begin{array}{l}\text { Change of } \\
\text { biomarkers in } \\
\text { pre- and post- } \\
\text { surgery } \\
\text { samples }\end{array}$ & $\begin{array}{c}50 \\
\text { Recruiting }\end{array}$ \\
\hline $\begin{array}{c}\text { NCT01773460 } \\
\text { Phase II }\end{array}$ & $\begin{array}{c}\text { German } \\
\text { Breast Group }\end{array}$ & $\begin{array}{c}\text { A Multicenter Randomized, } \\
\text { Double Blind, Placebo-Controlled, } \\
\text { Phase II Study to Compare Endocrine } \\
\text { Treatment Alone Versus Endocrine } \\
\text { Treatment With Everolimus in Patients } \\
\text { With HR+/HER2- Metastatic Breast } \\
\text { Cancer and Progression After Previous } \\
\text { Treatment with Exemestane } \\
\text { and Everolimus }\end{array}$ & $\begin{array}{l}\text { Everolimus is given beyond } \\
\text { progression vs placebo } \\
\text { is given beyond progression }\end{array}$ & $\begin{array}{l}\text { PFS } \\
\text { OS } \\
\text { CBR } \\
\text { Toxicity } \\
\text { Biological } \\
\text { markers }\end{array}$ & $\begin{array}{c}134 \\
\text { Recruiting }\end{array}$ \\
\hline $\begin{array}{l}\text { S1207 } \\
\text { Phase III }\end{array}$ & SWOG/NSABP & $\begin{array}{c}\text { A phase III randomized, } \\
\text { placebo-controlled clinical trial } \\
\text { evaluating the use of adjuvant } \\
\text { endocrine therapy }+/- \text { one year of } \\
\text { everolimus in patients with high-risk, } \\
\text { hormone receptor (HR)- } \\
\text { positive and HER2-negative } \\
\text { breast cancer: SWOG/NSABP S1207 }\end{array}$ & $\begin{array}{l}\text { Physician's choice adjuvant } \\
\text { endocrine therapy }+ \\
\text { everolimus } 10 \text { mg daily } \\
\text { for one year vs physician's } \\
\text { choice adjuvant endocrine } \\
\text { therapy + placebo }\end{array}$ & $\begin{array}{c}\text { DFS } \\
\text { OS } \\
\text { Safety } \\
\text { Adherence } \\
\text { QOL }\end{array}$ & $\begin{array}{c}3500 \\
\text { Recruiting }\end{array}$ \\
\hline
\end{tabular}

\section{REFERENCES}

[1] American Cancer Society, "Cancer Facts and Figures 2011," American Cancer Society, Atlanta, 2011.

[2] P. A. Greenberg, G. N. Hortobagyi, T. L. Smith, et al., "Long-Term Follow-Up of Patients with Complete Remission Following Combination Chemotherapy for Metastatic Breast Cancer," Journal of Clinical Oncology, Vol. 14, 1996, pp. 2197-205.

[3] S. Dawood, K. Broglio, A. M. Gonzalez-Angulo, et al., "Trends in Survival over the Past Two Decades among White and Black Patients with Newly Diagnosed Stage IV Breast Cancer," Journal of Clinical Oncology, Vol. 26, No. 23, 2008, pp. 4891-4898. doi:10.1200/JCO.2007.14.1168

[4] S. K. Chia, C. H. Speers, Y. D'Yachkova, et al., "The Impact of New Chemotherapeutic and Hormone Agents on Survival in a Population-Based Cohort of Women with Metastatic Breast Cancer," Cancer, Vol. 110, No. 5, 2007, pp. 973-979. doi:10.1002/cncr.22867

[5] S. Germano and L. O'Driscoll, "Breast Cancer: Understanding Sensitivity and Resistance to Chemotherapy and Targeted Therapies to Aid in Personalised Medicine," Current Cancer Drug Targets, Vol. 9, No. 3, 2009, pp. 398-418. doi:10.2174/156800909788166529

[6] M. C. De Martino, P. M. van Koetsveld, R. Pivonello, et al., "Role of the mTOR Pathway in Normal and Tumoral Adrenal Cells," Neuroendocrinology, Vol. 92, Suppl 1, 2010, pp. 28-34. doi:10.1159/000314280

[7] S. Huang and P. J. Houghton, "Targeting mTOR Signal- ing for Cancer Therapy," Current Opinion in Pharmacology, Vol. 3, No. 4, 2003, pp. 371-377. doi:10.1016/S1471-4892(03)00071-7

[8] M. A. Bjornsti and P. J. Houghton, "The TOR Pathway: A Target for Cancer Therapy," Nature Reviews Cancer, Vol. 4, No. 5, 2004, pp. 335-348. doi:10.1038/nrc1362

[9] R. H. Alvarez, V. Valero and G. N. Hortobagyi, "Emerging Targeted Therapies for Breast Cancer," Journal of Clinical Oncology, Vol. 28, No. 20, 2010, pp. 3366-3379. doi:10.1200/JCO.2009.25.4011

[10] N. Margariti, S. B. Fox, A. Bottini, et al., "Overcoming Breast Cancer Drug Resistance with mTOR Inhibitors, Could It Be a Myth or a Real Possibility in the ShortTerm Future?" Breast Cancer Research and Treatment, Vol. 128, No. 3, 2011, pp. 599-606. doi:10.1007/s10549-010-0986-9

[11] G. Perez-Tenorio, L. Alkhori, B. Olsson, et al., "PIK3CA Mutations and PTEN Loss Correlate with Similar Prognostic Factors and Are Not Mutually Exclusive in Breast Cancer," Clinical Cancer Research, Vol. 13, 2007, pp. 3577-3584. doi:10.1158/1078-0432.CCR-06-1609

[12] N. Shoman, S. Klassen, A. McFadden, et al., "Reduced PTEN Expression Predicts Relapse in Patients with Breast Carcinoma Treated by Tamoxifen," Modern Pathology, Vol. 18, 2005, pp. 250-259. doi:10.1038/modpathol.3800296

[13] L. A. deGraffenried, W. E. Friedrichs, D. H. Russell, et al., "Inhibition of mTOR Activity Restores TamoxifenResponse in Breast Cancer Cells with Aberrant Akt Activity," Clinical Cancer Research, Vol. 10, 2004, pp. 8059-8067. doi:10.1158/1078-0432.CCR-04-0035 
[14] E. A. Musgrove and R. L. Sutherland, "Biological Determinants of Endocrine Resistance in Breast Cancer," Nature Reviews Cancer, Vol. 9, No. 9, 2009, pp. 631-643.

[15] P. Chollet, C. Abrial, O. Tacca, et al., "Mammalian Target of Rapamycin Inhibitors in Combination with Letrozole in Breast Cancer," Clinical Breast Cancer, Vol. 7, No. 4, 2006, pp. 336-338. doi:10.3816/CBC.2006.n.047

[16] K. Berns, H. M. Horlings, B. T. Hennessy, et al., "A Functional Genetic Approach Identifies the PI3K Pathway as a Major Determinant of Trastuzumab Resistance in Breast Cancer," Cancer Cell, Vol. 12, 2007, pp. 395402. doi:10.1016/j.ccr.2007.08.030

[17] D. Harari and Y. Yarden, "Molecular Mechanisms Underlying ErbB2/HER2 Action in Breast Cancer," Oncogene, Vol. 19, No. 53, 2000, pp. 6102-6114. doi:10.1038/sj.onc. 1203973

[18] Product Information, "AFINITOR(R) Oral Tablets, Everolimus Oral Tablets," Novartis Pharmaceuticals Corporation (per FDA), East Hanover, 2012.

[19] Product Information, "Zortress(R) Oral Tablets, Everolimus Oral Tablets," Novartis Pharma Stein AG, Stein, 2010.

[20] J. Tabernero, F. Rojo, E. Calvo, et al., "Dose- and Schedule-Dependent Inhibition of the Mammalian Target of Rapamycin Pathway with Everolimus: A Phase I Tumor Pharmacodynamic Study in Patients with Advanced solid Tumors," Journal of Clinical Oncology, Vol. 26, 2008, pp. 1603-1610. doi:10.1200/JCO.2007.14.5482

[21] A. O'Donnell, S. Faivre, H. A. Burris 3rd, et al., "Phase I Pharmacokinetic and Pharmacodynamic Study of the Oral Mammalian Target of Rapamycin Inhibitor Everolimus in Patients with Advanced Solid Tumors," Journal of Clinical Oncology, Vol. 26, 2008, pp. 1588-1595. doi:10.1200/JCO.2007.14.0988

[22] L. W. C. Chow, J. Jassem, et al., "Phase 3 Study of Temsirolimus with Letrozole or Letrozole Alone in Postmenopausal Women with Locally Advanced or Metastatic Breast Cancer," Presented at the 29th Annual San Antonio Breast Cancer Symposium, San Antonio, 14-17 December 2006.

[23] T. Bachelot, C. Bourgier, C. Cropet, et al., "Randomized Phase II Trial of Everolimus in Combination with Tamoxifen in Patients with Hormone Receptor-Positive, Human Epidermal Growth Factor Receptor 2-Negative Metastatic Breast Cancer with Prior Exposure to Aromatase Inhibitors: A GINECO Study," Journal of Clinical Oncology, Vol. 30, 2012, pp. 2718-2724. doi:10.1200/JCO.2011.39.0708

[24] A. Awada, F. Cardoso, C. Fontaine, et al., "The Oral mTOR Inhibitor RAD001 (Everolimus) in Combination with Letrozole in Patients with Advanced Breast Cancer: Results of a Phase I Study with Pharmacokinetics," European Journal of Cancer, Vol. 44, No. 1, 2008, pp. 84-91. doi:10.1016/j.ejca.2007.10.003

[25] J. Baselga, V. Semiglazov, P. van Dam, et al., "Phase II Randomized Study of Neoadjuvant Everolimus Plus Letrozole Compared with Placebo Plus Letrozole in Patients with Estrogen Receptor-Positive Breast Cancer," Journal of Clinical Oncology, Vol. 27, 2009, pp. 2630-2637.
doi:10.1200/JCO.2008.18.8391

[26] F. Badin, M. Chambers, et al., "A Phase II Trial of Fulvestrant and RAD001 (Everolimus) in Patients with Metastatic Estrogen Receptor Positive Breast Cancer after Aromatase Inhibitor Failure: A Study in Progress," Presented at the 33rd Annual San Antonio Breast Cancer Symposium, San Antonio, 8-12 December 2010.

[27] J. Baselga, M. Campone, M. Piccart, et al., "Everolimus in Postmenopausal Hormone-Receptor-Positive Advanced Breast Cancer," New England Journal of Medicine, Vol. 366, No. 6, 2012, pp. 520-529. doi:10.1056/NEJMoa1109653

[28] J. S. Ross, E. A. Slodkowska, W. F. Symmans, et al., "The HER-2 Receptor and Breast Cancer: Ten Years of Targeted Anti-HER-2 Therapy and Personalized Medicine," Oncologist, Vol. 14, No. 4, 2009, pp. 320-368. doi:10.1634/theoncologist.2008-0230

[29] D. Jelovac and A. C. Wolff, "The Adjuvant Treatment of HER2-Positive Breast Cancer," Current Treatment Options in Oncology, Vol. 13, No. 2, 2012, pp. 230-239. doi:10.1007/s11864-012-0186-4

[30] J. Baselga, J. Cortes, S. B. Kim, et al., "Pertuzumab Plus Trastuzumab Plus Docetaxel for Metastatic Breast Cancer," New England Journal of Medicine, Vol. 366, No. 2, 2012, pp. 109-119. doi:10.1056/NEJMoa1113216

[31] F. Andre, M. Campone, R. O'Regan, et al., "Phase I Study of Everolimus Plus Weekly Paclitaxel and Trastuzumab in Patients with Metastatic Breast Cancer Pretreated with Trastuzumab," Journal of Clinical Oncology, Vol. 28, No. 34, 2010, pp. 5110-5115. doi:10.1200/JCO.2009.27.8549

[32] F. C. M. Dalenc, P. Hupperets, et al., "Everolimus in Combination with Weekly Paclitaxel and Trastuzumab in Patients (pts) with HER-2-Overexpressing Metastatic Breast Cancer (MBC) with Prior Resistance to Trastuzumab and Taxanes: A Multicenter Phase II Clinical Trial," American Society of Clinical Oncology Annual Meeting, Chicago, 4-8 June 2010.

[33] G. Jerusalem, A. Fasolo, V. Dieras, et al., "Phase I Trial of Oral mTOR Inhibitor Everolimus in Combination with Trastuzumab and Vinorelbine in Pre-Treated Patients with HER2-Overexpressing Metastatic Breast Cancer," Breast Cancer Research and Treatment, Vol. 125, No. 2, 2011, pp. 447-455. doi:10.1007/s10549-010-1260-x

[34] G. F. A. Jerusalem, C. Massacesi, et al., "Maintenance with Everolimus (RAD001) and Trastuzumab (T) after Discontinuation of Chemotherapy in Heavily Pre-Treated HER-2 + Metastatic Breast Cancer (MBC) Patients (pts): Pooled Data of Extension Cohorts of Phase Ib/II Studies," American Society of Clinical Oncology Annual Meeting, Chicago, 4-8 June 2010.

[35] M. G. L. Campone, C. Massacesi, et al., "Trastuzumab (H) and Everolimus (RAD001) Containing Regimens Are Safe and Active When Reintroduced in Patients (pts) with HER2-Overexpressing Metastatic Breast Cancer (MBC) Pre-Treated with Lapatinib [Abstract]," European Journal of Cancer Supplements, Vol. 8, 2010, p. 186. doi:10.1016/S1359-6349(10)70458-4

[36] P. K. Morrow, G. M. Wulf, J. Ensor, et al., "Phase I/II 
Study of Trastuzumab in Combination with Everolimus (RAD001) in Patients with HER2-Overexpressing Metastatic Breast Cancer Who Progressed on TrastuzumabBased Therapy," Journal of Clinical Oncology, Vol. 29, No. 23, 2011, pp. 3126-3132.

doi:10.1200/JCO.2010.32.2321

[37] I. A. B. H. Mayer, J. Bendel, et al., "A Phase Ib Trial of RAD001, an mTOR Inhibitor, with Weekly Cisplatin and Paclitaxel in Patients with HER2-Negative Metastatic Breast Cancer," 32nd Annual San Antonio Breast Cancer
Symposium, San Antonio, 9-13 December 2009.

[38] A. M. G. M. Gonzalez-Angulo, J. L. Murray, et al., "Open Label Randomized Clinical Trial of Standard Neoadjuvant Chemotherapy with Paclitaxel Followed by FEC (TFEC) vs the Combination of Paclitaxel and RAD001 Followed by FEC (TR-FEC) in Women with Triple Receptor-Negative Breast Cancer (TNBC)," American Society of Clinical Oncology Annual Meeting, Chicago, 3-7 June 2011. 